\title{
Study of Noncovalent Enzyme-Inhibitor Complexes and Metal Binding Stoichiometry of Matrilysin by Electrospray Ionization Mass Spectrometry
}

\author{
Rong Feng* \\ National Research Council of Canada, Biotechnology Research Institute, Montreal, Quebec, Canada \\ Arlindo L. Castelhano, Roland Billedeau, and Zhengyu Yuan ${ }^{\dagger}$ \\ Syntex-Canada, Mississauga, Ontario, Canada
}

Electrospray ionization mass spectrometry (ESI-MS) was used to study the noncovalent metallo-enzyme-inhibitor complexes of matrilysin (a matrix metalloproteinase of mass $18,720 \mathrm{u}$ ) under gentle experimental conditions and to determine the metal ion association stoichiometries in both the free enzyme and the complexes. The metal association stoichiometries of the free matrilysin were found to be highly sensitive to solution $\mathrm{pH}$ changes. At $\mathrm{pH}$ 2.2 the enzvme existed as metal-free apo-matrilysin and was not capable of binding an inhibitor. Ai pH 4.5-7.0 the enzyme associated specifically with zinc and calcium cations and became active in inhibitor binding. Although the stoichiometries of the metal cofactors varied (zero to two zinc and/or calcium ions) in the free enzyme dependent on solution $\mathrm{pH}$, the predominant form of the anzyme-inhibitor complexes in the $\mathrm{pH}$ range of $4.5-7.0$, in contrast, always had the metal association stoichiometry of $2 \mathrm{Zn}+2 \mathrm{Ca}$, which was the same stoichiometry the most active free metallo-enzyme had at the optimal pH of 7 . At the activity onset $\mathrm{pH}$ of 4.5 matrilysin existed mostly as apo-enzyme (but in a conformation different from the denatured one at $\mathrm{pH} \mathrm{2.2)} \mathrm{and} \mathrm{bound} \mathrm{to} \mathrm{an} \mathrm{inhibitor} \mathrm{slowly} \mathrm{(time} \mathrm{constant} ~ 2.5$ $\mathrm{min}$ ) to form the noncovalent metallo-enzyme-inhibitor complex. Of the two inhibitors studied, the one with the higher solution binding constant also produced larger ion signals for the noncovalent complex in the solvent-free gas phase, which pointed to the feasibility of the use of ESI-MS for inhibitor screening studies. (J Am Soc Mass Spectrom 1995, 6, 1105-1111)

$\mathrm{M}$ atrilysin (also referred to as pump-1 or MMP-7 in the biochemical literature) belongs to the matrix metalloproteinase (MMP) family that collectively degrades connective tissue matrices [1]. MMPs are involved in normal tissue remodeling, such as growth and wound healing, and have been implicated in diseases such as arthritis and cancer [1-12]. It is known [1-12] that MMPs require zinc and calcium cations to maintain their structural integrity and biological activities, and their metal binding stoichiometries vary among the enzymes. It is essential to study the structural and functional roles of the metal cofactors and to determine their stoichiometries in the enzyme to gain an in-depth understanding of a metallo-enzyme [1-12]. Due to the medicinal importance

Address reprint requests to Dr. Rong Feng, American Cvanamid Co., P.O. Box t00, Princeton, NJ 08543 or Dr. Zhengyu Yuan, Affymax Research Institute, 4001 Miranda Avenue, Palo Alto, CA 94.304. - Current address: American Cyanamid Co., P.O. Box t(10), Princeton, NJ 08543.

Current address: Affymax Research Institute, 4001 Miranda Avenue, Palo Alto, CA 94304 of matrilysin, various efforts have been put forward for its characterization [1-7], including design of effective small-molecule inhibitors for its inactivation. Typically these synthetic inhibitors are organic molecules of molecular weight (MW) several hundred units [4] and they bind to the enzyme noncovalently with varying binding constants. The study of the binding effectiveness of an inhibitor and its interactions with the enzyme plays a key role in the search for potential therapeutic agents.

The electrospray ionization (ESI) technique [13-15] has revolutionized biological mass spectrometry in the past few years because this extremely soft ionization technique generates intact multiply charged ions of large, nonvolatile, and labile biomolecules directly from solution. The rapid advance of electrospray ionization-mass spectrometry (ESI-MS) has produced a wide range of biochemical applications, such as (but not limited to) accurate mass measurements of various proteins [13-18] and oligonucleotides [16, 19], liquid chromatography-mass spectrometry (LC-MS) peptide 
mapping [20], tandem mass spectrometry structural studies of intact proteins [21-23] and oligonucleotides $[24,25]$, characterization of protein conformational states [26-29], and detection of short-lived enzyme reaction intermediates [30]. Several studies [31-33] also have demonstrated that protein-metal interactions and binding stoichiometries can be characterized by ESIMS. Furthermore, it has been shown [29,34-40] that ESI-MS has the remarkable capability to produce intact gaseous ions from spreific noncovalent complexes of proteins or oligonucleotides in solution. Although the structures and the binding nature of these noncovalent gas-phase complexes, which are of great fundamental interest, still are not understood fully, this unusual feature of ESI-MS could complement the traditional biochemical techniques that characterize enzyme-inhibitor complexes in solution. In this article we report the results of our ESI-MS study on the formation of noncovalent complexes between matrilysin and its small-molecule inhibitors, and the association stoichiometries of zinc and calcium cations in the enzyme-inhibitor complexes and in the free metallo-enzymes.

\section{Experimental}

\section{Mass Spectrometry}

A triple quadrupole mass spectrometer (API III, Sciex, Thornhill, Ontario, Canada) was used for the ESI-MS experiments. Only a brief description of the instrument will be given here because more details can be found elsewhere $[18,20,22,29]$. The instrument had a massto-charge ratio $(\mathrm{m} / z)$ range of 2470 and was fitted with a pneumatically assisted electrospray (ion spray) $[16,41]$ device. The aqueous sample solution was delivered to the electrosprayer at a flow rate of $1.0 \mu \mathrm{L} / \mathrm{min}$ by a syringe infusion pump (Model 22, Harvard Apparatus, South Natick, MA). Multiply charged protein ions were generated by electrospraying the sample solution at $4.5-4.8 \mathrm{kV}$ at room temperature and under atmospheric pressure. To minimize the dissociation of the noncovalent enzyme-inhibitor complexes in the gas phase by the ion-molecule collisions at the atmosphere-vacuum interface region, the voltage on the instrument sampling orifice was reduced, from the typical values of $80-120 \mathrm{~V}$ to $40-70 \mathrm{~V}$ to decrease the impact energies of the multiply charged ions during the desolvating ion-molecule collisions.

\section{Materials and Sample Handling}

A recombinant human matrilysin (average MW 18,720 u), which lacked the C-terminal extension of Arg-Lys-Lys in the amino acid sequence of the wild type $[5,6]$, but retained the biological activity [7], was produced by using the procedure previously described [7]. $\mathrm{ZnCl}_{2}$ and $\mathrm{CaCl}_{2}$ (concentrations as high as $5 \mathrm{mM}$ ) and other buffer salts were introduced at various enzyme preparation and purification stages [7]. To minimize nonspecific cation binding to matrilysin, the enzyme sample was exhaustively dialyzed against three batches of $10-\mathrm{mM}$ ammonium acetate buffer solutions at $\mathrm{pH} 7.0$ prior to the ESI-MS experiments to remove the excess of mbound $\mathrm{Zn}^{2}$, and $\mathrm{Ca}^{2}$ ions and other ESI-interfering buffer salts. The peptidehydroxamate inhibitors used in this study (structures shown in Figure 1), BB-16 (MW $393 \mathrm{u}$ ), and RS-39066 (MW $435 \mathrm{u}$ ), were synthesized at Syntex Canada and were used as provided without further purification. To effect the binding of the inhibitors to matrilysin, the dialyzed enzyme solution at $50-\mu \mathrm{M}$ concentration and containing $10-\mathrm{mM}$ ammonium acetate buffer was mixed with an inhibitor solution at 1:1 molar ratio. To evaluate the effects of enzyme conformational changes on the metal ion stoichiometry and inhibitor binding, the solution acidity was varied between $\mathrm{pH} 2$ and 7 by using acetic acid and/or ammonium hydroxide titration. The enzyme solutions were electrosprayed with the assistance of a pneumatic nebulizer; spray-enhancing organic modifiers, such as popularly used methanol or acetonitrile, were not added to the solutions to avoid solvent-induced enzyme denaturation.

\section{Results and Discussion}

\section{Effects of Solution $\mathrm{pH}$ on the Metal Binding of Matrilysin}

The activity of an enzyme typically shows strong dependence on solution acidity, due in large part to the $\mathrm{pH}$-induced conformational changes of the enzyme. The effects of solution acidity on matrilysin thus were investigated by varying $\mathrm{pH}$ from 2 to 7 during the ESI-MS experiments. At pH 2.2 (in 10\% acetic acid) the electrosprayed enzyme ions were detected in the form of metal-free apo-matrilysin and carried charges that ranged from $15+$ to $25+$ (Figure $2 \mathrm{a}$ ); no inhibitor binding was detected at this $\mathrm{pH}$. When the solution $\mathrm{pH}$ was increased to 4.5-7.0, a new charge distribution of lower-charged ions (charge states only up to $10+$ ), which resembled the charge distribution of the
BB-16

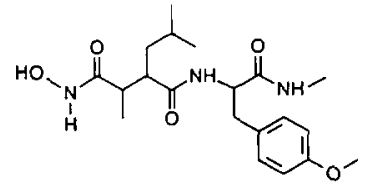

$\mathrm{C}_{20} \mathrm{H}_{31} \mathrm{~N}_{3} \mathrm{O}_{5}, \mathrm{MW} 393 \mathrm{Da}$

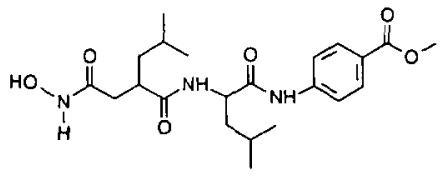

$\mathrm{C}_{22} \mathrm{H}_{33} \mathrm{~N}_{3} \mathrm{O}_{6}$, MW $435 \mathrm{Da}$
Figure 1. Structures and molecular weights of the noncovalent matrilysin inhibitors BB-16 and RS-39066. 

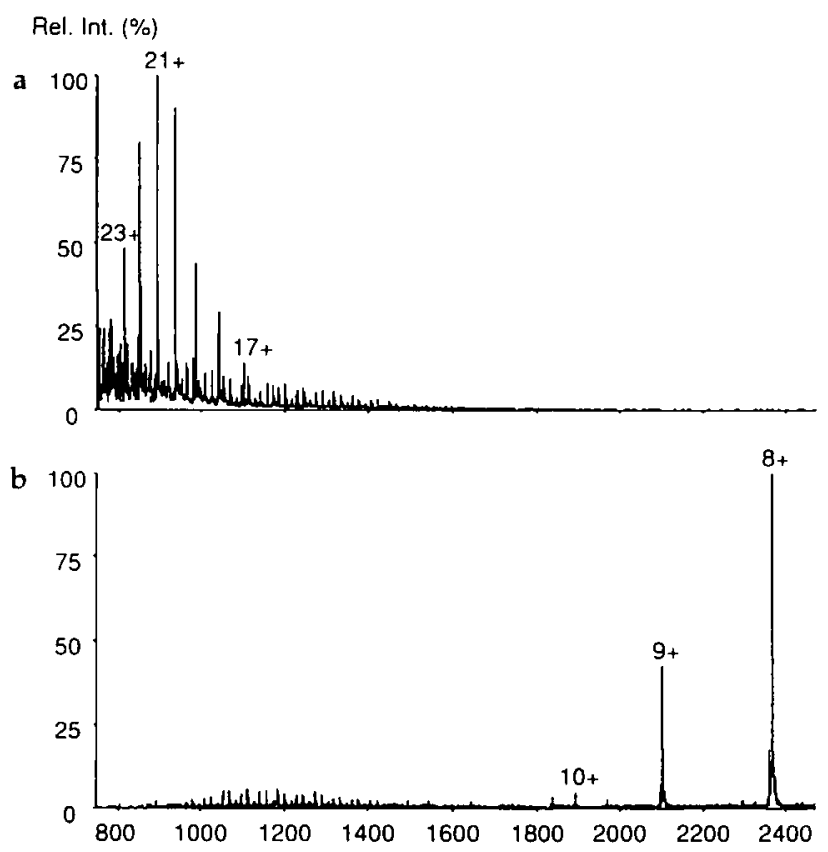

Figure 2. ESI mass spectra of matrilysin at (a) $\mathrm{pH} 2.2$ (in $10 \%$; acetic acid) and (b) $\mathrm{pH} 7.0$ (in $10-\mathrm{mM}$ ammonium acetate). The masses of the major species in the spectra are (a) $18,720 \pm 2$ u for apo-matrilysin and (b) $18,930 \pm 2$ u for metallo-matrilysin that contains two zine and two calcium ions. The representative charge states of the enzyme ions are shown in the spectra. The charge distribution in (b) is truncated due to the limited scan range $(m / z 2470)$ of the instrument.

enzyme-inhibitor complexes, was observed in the high mass-to-charge ratio region of the ESI mass spectrum (Figure 2b). Mass calculations, which took into account the displacements of hydrogen ions by the divalent metal cations, revealed that in addition to the metalfree apo-matrilysin, several metallo-matrilysins that contain one to two $\mathrm{Zn}^{2+}$ and/or $\mathrm{Ca}^{2+}$ ions also were present in this $\mathrm{pH}$ range (Figures $3 \mathrm{a}$ and $3 \mathrm{~b}$ ). The association stoichiometry of the metal ions exhibited a strong $\mathrm{pH}$ dependence. At $\mathrm{pH}$ 6.0, despite the shift of the charge distribution to the low charge state region, apo-matrilysin remained the major species (Figure 3a), whereas at pH 7.0 metallo-matrilysin with $2 \mathrm{Zn}^{2+}$ and $2 \mathrm{Ca}^{2+}$ was predominant and apo-matrilysin was barely visible (Figure 3b).

All MMPs require a $\mathrm{Zn}^{2+}$ ion to assist the catalysis reaction at the enzyme active site; they also retain a varying number of additional $\mathrm{Zn}^{2+}$ and $\mathrm{Ca}^{2+}$ ions for structural stability [1-12]. The molar ratio of zinc and protein in the matrilysin system recently has been determined to be $2.2: 1$ by the atomic absorption technique [3], and stromelysin (a related MMP) has been shown, using atomic absorption [3] and ESI-MS [33] techniques, to contain two to three zinc ions $[3,33]$ and zero to two calcium ions [33] per enzyme molecule. The specificity of the multiple metal binding in matrilysin and its strong $\mathrm{pH}$ dependence could be rationalized on the basis of enzyme high-order structures.
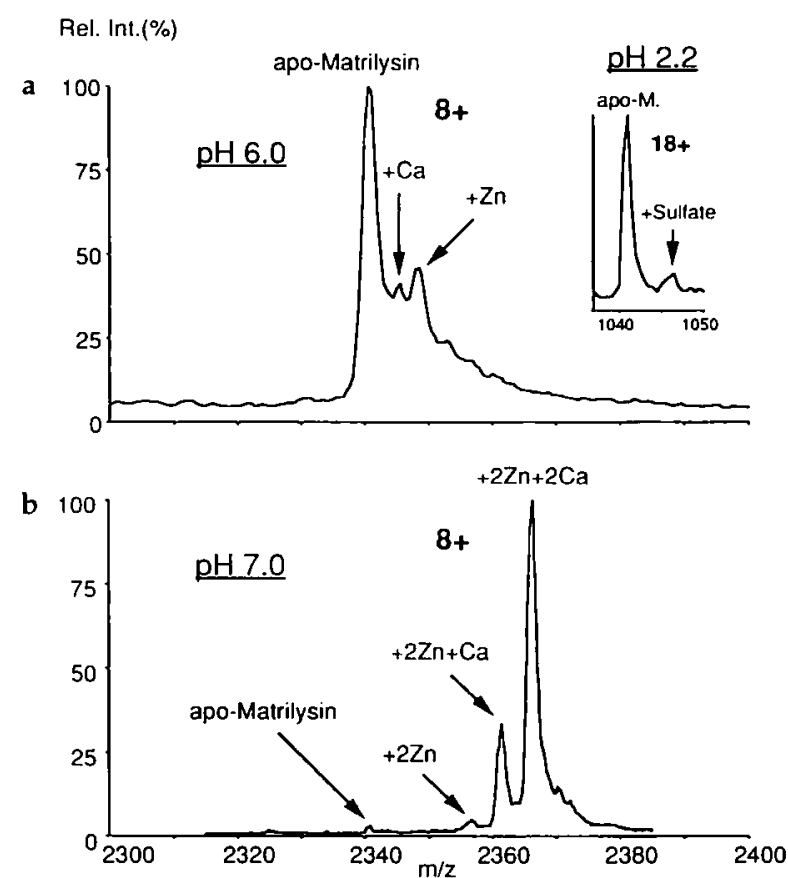

Figure 3. Partial ESI mass spectra of various matrilysin species detected at $\mathrm{pH}$ (a) 6.0, (b) 7.0 and (a, inset) 2.2 . The $8+$ chargestate ions are shown in (a) and (b), and $18+$ in (a, inset). The association stoichiometries of the zinc and calcium ions in these enzyme species are as indicated.

Specific cation binding in a protein is typically due to the cooperative chelating effect of several electrondonating amino acids, such as histidine, cysteine, aspartic acid, and so forth, that are closely placed in space to form a binding pocket. Because these amino acids often are separated by larger distances in the primary sequence, changes in the tertiary and/or secondary structures could disrupt the metal binding pockets of the protein and result in lower binding affinities toward the metal cations. Various ESI-MS studies [26-29] have shown that denatured proteins tend to carry more charges than the proteins in their native state. At pH 2.2 matrilysin was acid-denatured because it was completely inactive and its ions carried as many as $\mathbf{2 5}$ protons. Thus, it was not surprising that only the apo-matrilysin ions with "denatured" charge distribution appeared in the ESI mass spectrum (Figure 2a) and no specific metal ion association was detected (Figure 3a, inset). At $\mathrm{pH} 4.5-7.0$, the presence of the enzyme catalytic activity, the shift of the ESI charge distribution to lower charge states, and the incorporation of the metal ions all indicated that the enzyme had assumed new conformations and the metal binding pockets had been formed partially or fully. The changing stoichiometry of $\mathrm{Zn}^{2+}$ and $\mathrm{Ca}^{2+}$ ions implied that several populations of the enzyme with varying conformational structures existed between $\mathrm{pH}$ 4.5 and 7.0 and the differences in their metal chelating environments resulted in a range of binding selectivities and efficiencies. 
Formation and Detection of Noncounlent

Enzyme-Inhibitor Complexes

Although several species of metallo-matrilysin, with metal association stoichiometries ranging from one $\mathrm{Zn}^{2+}$ or one $\mathrm{Ca}^{2+}$ to two $\mathrm{Zn}^{2+}$ and two $\mathrm{Ca}^{2+}$, were detected (Figure 3), only the two forms that contained either two $\mathrm{Zn}^{2+}$ and two $\mathrm{Ca}^{2+}$, or two $\mathrm{Zn}^{2+}$ and one $\mathrm{Ca}^{2+}$, appeared to be involved in binding an inhibitor (Figure 4). At pH 7.0 matrilysin formed a metallo-enzyme-inhibitor complex with the organic compound BB-16, and the metal ion association stoichiometry of the major complex (data not shown) was the same as that of the major species of the free metallo-enzymes $(2 \mathrm{Zn}+2 \mathrm{Ca})$ at $\mathrm{pH} 7.0$. Apo-matrilysin was the major species in solution at $\mathrm{pH} 6.0$ (Figure 3a), although minor metallo-matrilysins that contained a single $\mathrm{Zn}^{2+}$ or $\mathrm{Ca}^{2 *}$ ion also were present. Because matrilysin

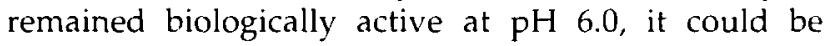
possible that the "native-like" apo-matrilysin also might be able to bind the inhibitor. However, upon addition of the inhibitor BB-16, the complex that contained two $\mathrm{Zn}^{2+}$ and two $\mathrm{Ca}^{2+}$ ions plus one BB-16 was once again produced as the predominant species (Figure 4a). This indicated that the major inhibitorbinding form of the several metallo-matrilysins was the form that had the metal association stoichiometry of $2 \mathrm{Zn}+2 \mathrm{Ca}$. The optimal $\mathrm{pH}$ value for the matrilysin catalytic activity is around $7[2,4]$, and it is no coincidence that the major species of the free metallomatrilysins that appeared at $\mathrm{pH} 7.0$ (Figure $3 \mathrm{~b}$ ) had the same metal association stoichiometry as the major metallo-enzyme-inhibitor complex at various $\mathrm{pHs}$. Apparently, both the $\mathrm{pH} 7$ free enzyme and the enzyme-inhibitor complex possessed the optimal conformation for the specific zinc and calcium binding. It was evident that the complex formed between the inhibitor and the most active $2 \mathrm{Zn}+2 \mathrm{Ca}$ metallo-matrilysin was so much more stable than all other forms of the enzyme that even at nonoptimal pHs it emerged as the major species in solution. In other words, the complex formation had actually "locked" the enzyme molecule in a particular conformation or state due to the stabilizing binding interactions. Because no apo-matrilysin was detected at $\mathrm{pH} 6.0$ in the presence of the inhibitor (Figure 4), complex formation between the inhibitor and metallo-matrilysin appeared to be nearly complete in solution, despite the nonoptimal conditions used.

In Figure 4 the metallo-matrilysins that lacked the inhibitor (near $m / z 2370$ ) on the left side of the inhibitor-containing complexes (near $m / z 2420$ ) had the metal compositions of $2 \mathrm{Zn}+2 \mathrm{Ca}$ (major) and $2 \mathrm{Zn}+$ $\mathrm{Ca}$ (minor), which were obviously due to the gas-phase dissociation of the noncovalent metallo-enzyme-inhibitor complexes of the same metal association stoichiometries because the nonbinding free enzyme should mostly appear as apo-matrilysin at pH 6.0 (Figure $3 a$ ). Such gas-phase collisional dissociations could be avoided by lowering the orifice voltage on the

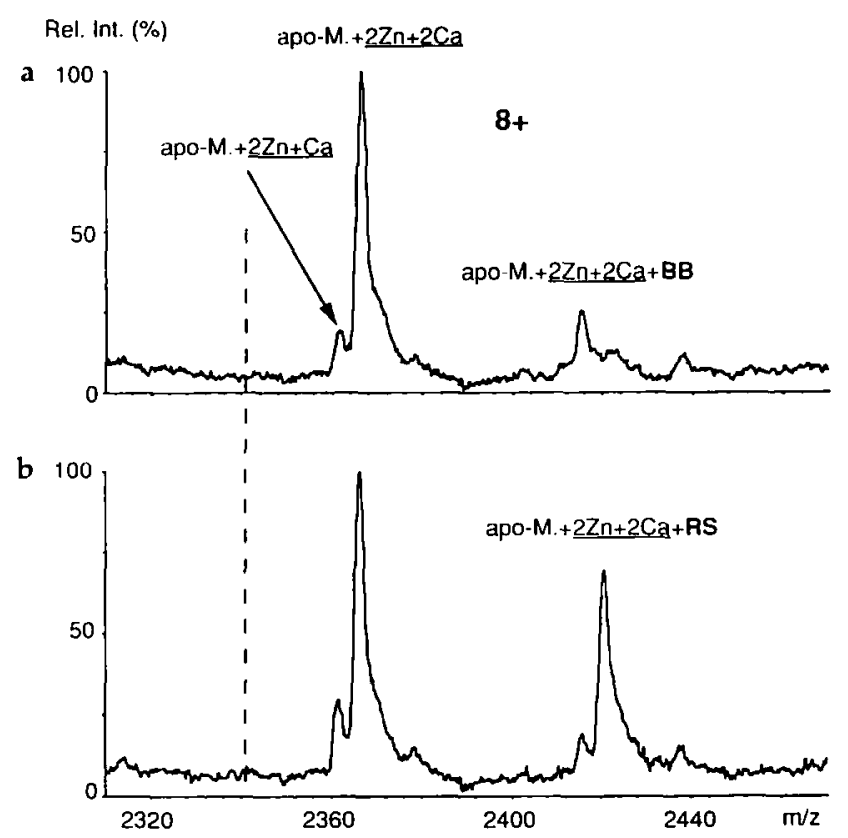

Figure 4. Partial ESI mass spectra that show the $8+$ charge-state ions from the noncovalent complexes of matrilysin with inhibitors (a) BB-16 (labeled as BB) and (b) RS-39066 (labeled as RS) at $\mathrm{pH}$ 6.0. The zinc and calcium association stoichiometries of the detected species are as indicated. The ion signals near $m /=2370$ are due to the gas-phase collisional dissociation of the complex ions near $m / z 2420$ at the relatively high orifice voltage of $70 \mathrm{~V}$. The vertical dashed line indicates the expected mass-to-charge ratio position of the $8+a p(0-$ matrilysin $(a p o-M$.$) ion in the spectra.$

instrument from the typical operating range of 80-120 $\mathrm{V}$ to $40-70 \mathrm{~V}$ (Figure 5a). However, these compromising conditions often resulted in lower measurement sensitivities and broad peaks in the ESI mass spectra due to insufficient ion desolvation [29]. Consistent with the typical fragility of the gas-phase noncovalent protein complexes, merely increasing the orifice voltage from 60 to $70 \mathrm{~V}$ would cause $\sim 50 \%$ of the metallomatrilysin-inhibitor complexes to dissociate (Figure $5 b$ ). At $80 \mathrm{~V}$ only $\sim 25 \%$ of the gas-phase complex remained and at $140 \mathrm{~V}$ the collisional dissociation was complete. However, these collisional experiments did not produce apo-matrilysin from either free metallomatrilysins or metallo-enzyme-inhibitor complexes, which indicated that the enzyme bound the metal ions much more tightly than the inhibitors in the gas phase. Surprisingly, the complex ions of the $8+$ charge state dissociated more readily than those of the $9+$ (Figure 5), which appeared to be opposite to what one would expect on the basis of either the Coulombic stabilities of the multiply charged complex ions or the activation energy uptakes during the ion-molecule collisions.

In the experiment shown in Figure $4 \mathrm{~b}$ another inhibitor (RS-39066) was used for the noncovalent complex formation. The basic features of Figure $4 \mathrm{~b}$ were very similar to those of Figure $4 a$, except that in the former the ion signal due to the major metallo-matrilysin-inhibitor complex was approximately three times larger. Notice also that the weaker complex signal on 


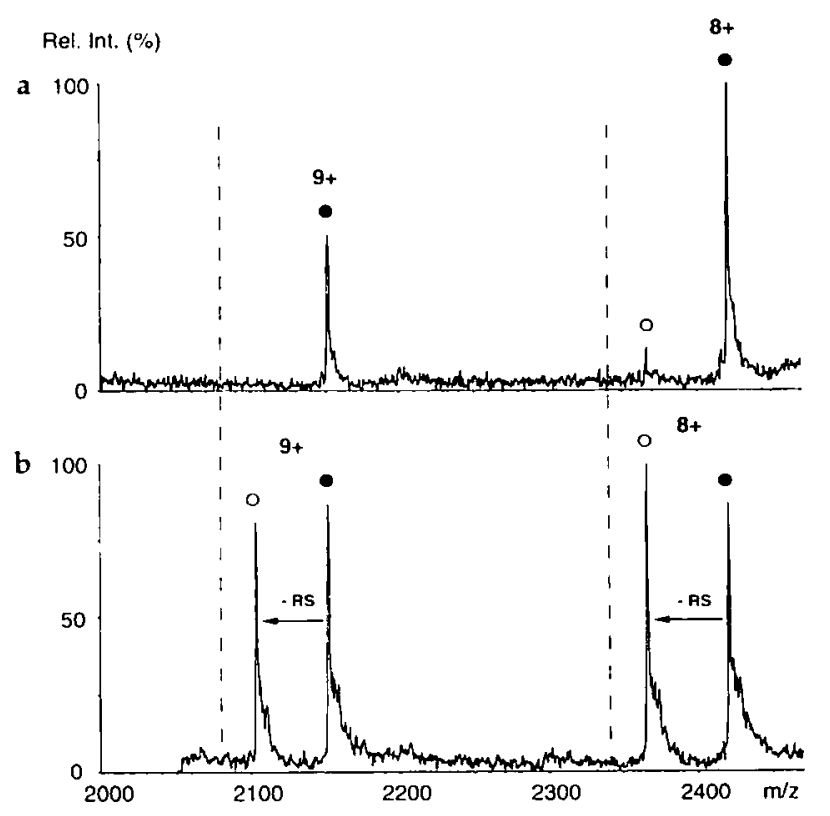

Figure 5. Partial ESI mass spectra that show the $8+$ and $9+$ charge-state ions from the noncovalent complexes of matrilysin with inhibitor RS-39066 at $\mathrm{pH} 7.0$ and at the instrument interface orifice voltages of (a) 60) $\mathrm{V}$ and (b) $70 \mathrm{~V}$. The filled circles (O) represent the major matrilysin-inhibitor complex that has the metal association stoichiometry of $2 \mathrm{Zn}+2 \mathrm{Ca}$ and the open circles $(O)$ the inhibitor-lacking imetallo-enzyme of the same $2 \mathrm{Zn}+$ 2Ca metal stoichiometry due to the gas-phase collisional dissociation of the noncovalent complex. The vertical dashed lines indicate the expected mass-to-charge ratio positions of the $8+$ and $9+$ apo-matrilysin ions in the spectra.

the left side of the major complex signal, which was from the enzyme-inhibitor complex having the $2 \mathrm{Zn}+$ Ca metal association stoichiometry, became more visible in Figure 4b. Because RS-39066 has a matrilysin binding constant $\sim 3$ orders of magnitude higher than BB-16 $\left(K_{\mathrm{d}}<4 \mathrm{nM}\right)$, it is expected that the former would associate with metallo-matrilysins more tightly than the latter in solution. Evidently the order of the relative stability of the two noncovalent matrilysin-inhibitor complexes still held true in the solvent-free gas phase. The stronger RS-39066-metallo-matrilysin complexes survived the gas phase collisional desolvation process better in the instrument atmosphere-vacuum interface region and produced stronger ion signals for the intact complexes, which included the weaker complex that had the $2 \mathrm{Zn}+\mathrm{Ca}$ metal association stoichiometry (Figure $4 \mathrm{~b}$ ). However, it was intriguing to notice that the relationship between the gas-phase ion intensities and the solution-phase binding constants of the complexes was not linear (e.g., a difference of factor 3 in the former versus that of -3 orders of magnitude in the latter). This perhaps was due to the structural changes the complexes experienced during the transition from solution to the gas phase, because the original tertiary and secondary structures of the complexes in solution might not survive intact in the solvent-free gas phase after such a drastic environment change. Despite this nonlinearity in relationship, a systematic study that uses a wide range of matrilysin inhibitors may nevertheless establish a useful correlation between the data from these two phases and further extend the usage of ESI-MS to inhibitor binding assays.

\section{Solution Equilibrium among Apo- and Metallo- Enzymes and Enzyme-Inhibitor Complexes}

Although matrilysin is most active around $\mathrm{pH} 7$, its enzymatic activities could be detected at pHs as low as 4.5 and as high as $9.5[2,4]$. At the onset $\mathrm{pH}$ of 4.5 the enzyme barely had any activity and ESI-MS measurements showed that it existed mostly as apo-matrilysin, but in a conformation different from the denatured one at $\mathrm{pH}$ 2.2. It was intriguing to see whether complex formation also could be effected at this onset $\mathrm{pH}$. In the experiments that followed the inhibitor RS-39066 was added to apo-matrilysin at $\mathrm{pH} 4.5$ and the ion signals of the major matrilysin species were monitored at various time intervals. Remarkably, the ion signals of the matrilysin-inhibitor complex with the $2 \mathrm{Zn}+$ $2 \mathrm{Ca}$ metal association stoichiometry appeared within 1 min and kept on rising up to $25 \mathrm{~min}$ with the simultaneous decline in the signal strength of apomatrilysin (Figures 6 and 7). These data showed that the distributions of the enzyme species in solution were shifting slowly to favor metallo-matrilysins due to the complex formation between the inhibitor and the enzyme at $\mathrm{pH} 4.5$ (Figure 8). Establishment of the new solution equilibrium under such unfavorable conditions also indicated that the metallo-matrilysin-inhibitor complexes were more stable than both apomatrilysin and various metallo-matrilysins. From Figure 7 the time constant of the equilibrium shift at $\mathrm{pH}$ 4.5 was estimated to be $\sim 2.5 \mathrm{~min}$, at which half of the apo-matrilysin had been converted to the metal-containing enzyme-inhibitor complex. In addition to gaining insight into the reaction kinetics of the inhibitor and metal binding of matrilysin, the data further demonstrated that the most active form of the enzyme required specifically two $\mathrm{Zn}^{2+}$ and two $\mathrm{Ca}^{2+}$ ions for inhibitor binding, and the predominant metal association stoichiometry of $2 \mathrm{Zn}+2 \mathrm{Ca}$ in the enzyme-inhibitor complex was determined intrinsically by the highorder structures of the complex and was $\mathrm{pH}$ independent.

\section{Conclusions}

This study demonstrates that the noncovalent protein-metal and protein-metal-inhibitor complexes of matrilysin can be detected and characterized by using ESI-MS under gentle experimental conditions. Encouragingly, the inhibitor with the higher solution binding constant also produces larger ion signals for the noncovalent complex in the solvent-free gas phase, which points to the feasibility of the use of ESI-MS for inhibitor screening studies. Additionally, the data il- 


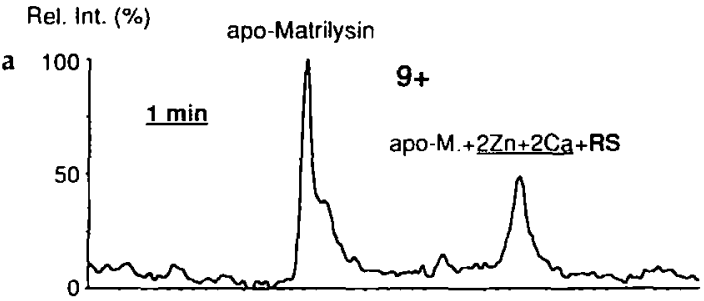

b
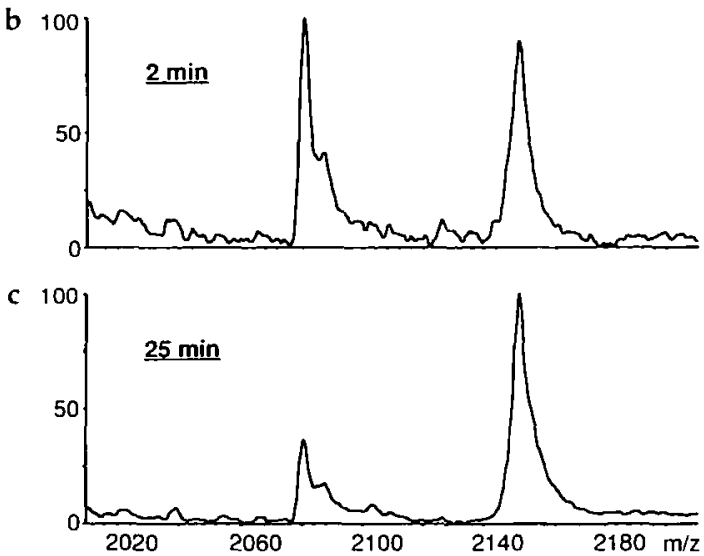

Figure 6. Partial ESI mass spectra that show the $9+$ charge-state ions of apo-matrilysin and its noncovalent complex with metal ions and inhibitor RS-39066 (labeled as RS) at $\mathrm{pH} 4.5$ and orifice voltage of $60 \mathrm{~V}$, and at reaction times of (a) $1 \mathrm{~min}$, (b) $2 \mathrm{~min}$, and (c) $25 \mathrm{~min}$

lustrate that ESI-MS can be used to monitor an enzyme-inhibitor binding reaction in real time and provide useful reaction kinetics information.

From a bio-analytical point of view, the data show that ESI-MS provides a convenient and precise means to determine the metal ion association stoichiometries in both the free metallo-enzymes and the enzymeinhibitor complexes. The number of metal ions in the free matrilysin is found to be highly sensitive to solution $\mathrm{pH}$ changes (e.g., zero to two $\mathrm{Zn}^{2-}$ and/or $\mathrm{Ca}^{2+}$ ions in the $\mathrm{pH}$ range of $6-7$ ). In contrast, the predominant stoichiometry of the metal ions $(2 \mathrm{Zn}+2 \mathrm{Ca})$ in

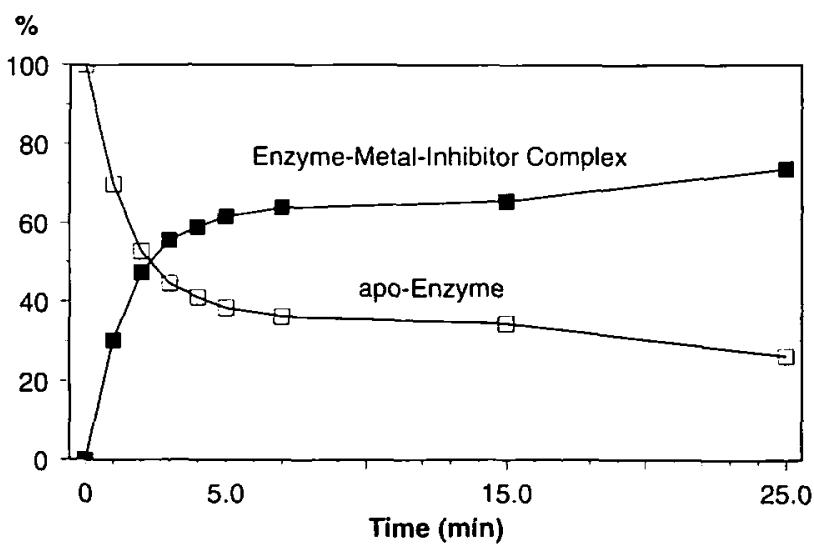

Figure 7. Plots of the relative signal intensities of noncovalent metallo-matrilysin-RS-39066 complex ( $\square$ ) and apo-matrilysin ( $\square$ ) versus time at $\mathrm{pH} 4.5$.

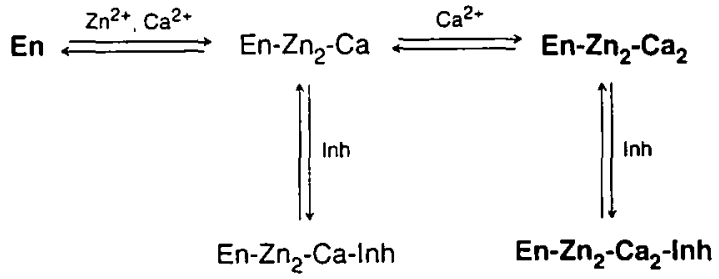

Figure 8. Proposed solution equilibrium of various matrilysin species. En denotes the apo-enzyme and Inh denotes the inhibitor. The species shown in boldface are the major enzyme forms detected by ESI-MS.

the enzyme-inhibitor complex is found to be $\mathrm{pH}$ independent (in the complex formation $\mathrm{pH}$ range of 4.5-7.0) because the sites of the specific metal bindings are fundamentally established by the enzyme high-order structures and secured by the complex formation. Thus, determination of the intrinsic metal binding stoichiometry in an enzyme via the enzyme-inhibitor complex (i.e., using the complex as a flag to signal the presence of the optimal enzyme conformation) appears to be a more reliable alternative to that via the free enzyme.

\section{Acknowledgments}

A major part of this work was presented at the Annual Meeting of the New York Academy of Sciences, January 19-22, 1994 (abstract page 489) and the 42nd ASMS Conference on Mass Spectrometry and Allied Topics, May 29-June 3, 1994 (abstract page 305 ). The authors thank J. Barnett for kindly providing the recombinant matrilysin sample for this study and $R$. Uppington for valuable experimental assistance.

\section{References}

1. Woessner, J. F., Jr. FASEB J. 1991, 5, 2145-2154.

2. Woessner, J. F., Jr.; Taplin, C. J. J. Biol. Chem. 1988, 263, $16918-16925$.

3. Soler, D.; Nomizu, T.; Brown, W. E.; Chen, M.; Ye, Q.-Z.; Van Wart, H. E.; Auld, D. S. Biochem. Biophys. Re's. Commun. 1994, 201, 917-923.

4. Crabbe, T.; Willenbrock, F.; Eaton, D.; Hynds, P.; Carne, A. F.; Murphy, G.; Docherty, A. J. P. Biochemistry 1992, 31, 8500-8507.

5. Quantin, B.; Murphy, G.; Breathnach, R. Bioch'mistry 1989, 28, 5327-5334.

6. Muller, D.; Quantin, B.; Gesnel, M.-C.; Millon-Collard, R.; Abecassis, J.; Breathnach, R. Biochem. /. 1988, 253, 187-192.

7. Barnett, J.; Straub, K.; Nguyen, B.; Chow, J.; Suttman, R.; Thompson, K.; Tsing, S.; Benton, P.; Schatzman, R.; Chen, M.; Chan, H. Protein Express. Purif. 1994, 5, 27-36.

8. Willenbrock, F.; Murphy, G.; Phillips, I. R.; Brocklehurst, K. FEBS Lett. 1995, 358, 189-192.

9. Lovejoy, B.; Cleasby, A.; Hassell, A. M.; Longley, K.; Luther, M. A.; Weigl, D.; McGeehan, G.; McElroy, A. B.; Drewry, D.; Lambert, M. H.; Jordan, S. R. Science 1994, 263, 375-377.

10. Housley, T. J.; Baumann, A. P.; Braun, I. D.; Davis, G.; Seperack, P. K.; Wilhelm, S. M. I. Biol. Che'm. 1993, 268, 4481-4487.

11. Salowe, S. P.; Marcy, A. I.; Cuca, G. C.; Smith, C. K.; Kopka, I. E.; Hagmann, W. K.; Hermes, J. D. Biochemistry 1992, 31, $4535-4540$. 
12. Park, A. J.; Matrisian, L. M.; Kells, A. F.; Pearson, R.; Yuan, Z.; Navre, M. J. Biol. Chem. 1991, 266, 1584-1590.

13. Fenn, J. B.; Mann, M.; Meng, C. K.; Wong, S. F.; Whitehouse, C. M. Science 1989, 246, 64-71.

14. Smith, R. D.; Loo, J. A.; Ogorzalek Loo, R. R.; Busman, M.; Udseth, H. R. Mass Spectront. Rev. 1991, 10, 359-452.

15. Chait, B.; Kent, S. B. H. Science 1992, 257, 1885-1894.

16. Covey, T. R.; Bonner, R. F.; Shushan, B. I.; Henion, J. Rapid Commun. Mass Spectrom. 1988, 2, 249-256.

17. Henry, K. D.; Quinn, J. P.; McLafferty, F. W. I. Am. Chem. Soc. 1991, 113, 5447-5449.

18. Feng, R; Konishi, Y. Anal. Chem. 1992, 64, 2090-2095.

19. Limbacl, P. A.; Crain, P. F.; McCloskey, J. A. I. Am. Soc. Mass Spectrom. 1995, 6, 27-39.

20. Covey, T. R.; Huang, E. C.; Henion, J. D. Anal. Chem. 1991, $63,1193-1200$.

21. Loo, J: A.; Edmonds, C. G, Smith, R. D. Science 1990, 248, 201-204.

22. Feng, R.; Konishi, Y. Anal. Chem. 1993, 65, 645-649.

23. Chorush, R. A.; Little, D. P,; Beu, S. C.; Wood, T. D; McLafferty, F. W. Annt Chem. 1995, 67, 1042-1046.

24. McLuckey, S. A.; Van Berkel, G. J.; Glish, G. L. I. Am. Soc. Mass Spectrom. 1992, 3, 60-70.

25. Little, D. P.; Chorush, R. A.; Speir, J. P.; Senko, M. W.; Kelleher, N. L.; McLafferty, F. W. I. Am. Chem. Soc. 1994, $116,4893-4897$

26. Chowdhury, S. K, Katta, V.; Chait, B. T. I. Am. Chem; Soc. $1990,112,9012-9013$.

27. Le Blanc, J. C. Y,; Beuchemin, D.; Siu, K. W. M.; Guevremont, R.; Berman, S. S. Org. Mass Spectrom. 1991, 26, 831-839.
28. Suckau, D, Shi, Y.; Beu, S. C; Senko, M. W; Quinn, J. P. Wampler, F. M., II, MeLafferty, F. W. Proc. Natl Acad Sci USA 1993, 90, 790-793.

29. Feng, R.; Konishi, Y. J. Am. Soc. Mäss Spectrom. 1993, 4, 638-645.

30. Stevenson, D. E.; Feng, R.; Storer, A. C. FEBS Lett. 1990, 277, $112-114$.

31. Hutchens, T. W.; Allen, M. H., Li, C. M, Yip, T.T. FEBS Lett. 1992, 309, 170-174.

32. Yu, X. L.; Wojciechowski, M.; Fenselau, C. Anal. Chem. 1993, 65, 1355-1359.

33. Hu, P, Ye, Q.Z.; Loo, J. A. Anal. Chem. 1994, 66, 4190-4194.

34. Ganem, B; Li, Y.-T; Henion, J. D. J. Am. Chem. Soc. 1991, $113,6294-6296$.

35. Ganem, B,; Li, Y.-T.; Henion, J. D. J. Am. Chem. Soc. 1991, 113, 7818-7819.

36. Baca, M., Kent, B. H. J. Am. Chem. Soc. 1992, 114, 3992-3993.

37. Ganguly, A. K; Pramanik, B. N.; Tsarbopoulos, A.; Covey, T. R. Huang, E.; Fuhrman, S. A. J. Am. Chem. Soc. 1992, 114, $6559-6560$.

38. Light-Wahl, K. L.; Springer, D. L.; Winger, B. E.; Edmonds, C, G.; Camp, D. G., II; Thrall, B. D, Smith, R. D. I. Am. Chem. Soc. 1993, 115, 803-804.

39. Ogorzalek Loo, R. R, Goodlett, D. R.; Smith, R. D, Loo, J. A. I. Am. Chemt. Soc. 1993, 115, 4391-4392.

40. Li, Y.-T; Hsieh, Y.L; Henion, J. D.; Senko, M. W, McLafferty, F. W., Ganem, B. J. Am. Chem. Soc. 1993, 115, 8409-8413

41. Bruins, A. P.; Covey, T. R.; Henion, J. D. Arial. Chem. 1987, $59,2642-2646$. 